\title{
RENCANA PELAKSANAAN PEMBELAJARAN (RPP) GURU BAHASA INGGRIS DI SD NEGERI KUNCIRAN 6
}

\author{
Alfira Fzriandina ${ }^{1}$, Fitri Alia ${ }^{2}$, Yanti Ardian Ningsih ${ }^{3}$ \\ Universitas Muhammadiyah Tangerang \\ Hmadandina@gmail.com,Fitrialia406@gmail.com
}

\begin{abstract}
This study was to describe of Lesson Plan (RPP) of English Language at Elementary School at SD Negeri Kunciran 6 by using descriptive qualitative method. The result of study was indicator formula including the clear aspect and the completeness indicator and some part of lesson plan writing everything it was from the basic competence. Material concerned to learning indicator but only writing the essential material. Learning activity before describing the objective of right competence. The choice of resource and learning media were related to indicators. The scoring included the whole indicators, and scoring tools were not related to scoring criteria.
\end{abstract}

Keywords: RPP, Language English

\begin{abstract}
Abstrak: Penelitian ini bertujuan mendeskripsikan RPP Bahasa Inggris di SD Negeri Kunciran 6 dengan metode deskriptif kualitatif. Hasil penelitian yaitu rumusan indikator mencakup aspek kejelasan dan kelengkapan cakupan indikator, dan sebagian RPP menyalin apa adanya dari kompetensi dasar. Materi mengacu indikator pembelajaran tetapi hanya berupa pencantuman pokok-pokok materi. Kegiatan pembelajaran belum menjabarkan tahapan pencapaian kompetensi secara tepat. Pemilihan sumber dan media pembelajaran sesuai indikator. Penilaian belum mencakup seluruh indikator, dan alat penilaian tidak disertai dengan kriteria penilaian.
\end{abstract}

Kata Kunci: RPP, Bahasa Inggris

\section{PENDAHULUAN}

Pendidikan di Negeri Kesatuan Republik Indonesia (NKRI) telah mengalami perubahan-perubahan kebijakan pendidikan. Perubahan yang dilakukan oleh pemerintah tersebut diharapkan dapat memajukan sumber daya manusia di Indonesia sehingga mendorong kemajuan bangsa. Memajukan kompetensi pembelajaran pada dunia pendidikan dapat dilakukan dengan membuat Rencana Pelaksanaan Pembelajaran (RPP). Pada hakikatnya penyusunan RPP bertujuan merancang pengalaman belajar siswa untuk mencapai tujuan pembelajaran. Menurut Mulyana Fondatia : Jurnal Pendidikan Dasar

Volume 4, Nomor 1, Maret 2020; 53-66 https://ejournal.stitpn.ac.id/index.php/fondatia 
(2012: 1) alasan pentingnya membuat RPP yaitu dapat menolong guru untuk memikirkan pelajaran sebelum pelajaran itu diajarkan sehingga kesulitan belajar dapat diramalkan dan jalan keluarnya dapat dicari. Guru dapat mengorganisasi fasilitas, perlengkapan, alat bantu pengajaran, waktu dan isi dalam rangka untuk mencapai tujuan belajar seefektif mungkin serta menghubungkan tujuan dan prosedur kepada tujuan keseluruhan dari mata pelajaran yang diajarkan.

Penelitian ini difokuskan pada RPP. Menggunakan RPP menurut pakar pendidikan cukup efektif dalam meningkatkan kualitas anak didik. Menurut Muslich (2008: 45), Perencanaan Pelaksanaan Pembelajaran (RPP) adalah rancangan pembelajaran mata pelajaran per unit yang akan diterapkan guru dalam pembelajaran di kelas. Berdasarkan RPP inilah seorang guru diharapkan dapat menerapkan pembelajaran secara terprogram. Sebuah RPP harus mempunyai daya terap yang tinggi. Tanpa perencanaan yang matang, target pembelajaran akan sulit tercapai secara maksimal. Oleh karena itu, kemampuan membuat RPP merupakan langkah awal yang harus dimiliki guru dan calon guru, serta sebagai muara dari segala pengetahuan teori, keterampilan dasar, dan pemahaman yang mendalam tentang obyek belajar dan situasi pembelajaran.

Tujuan penelitian ini adalah mendeskripsikan RPP yang digunakan guru Bahasa Inggris di SD Negeri KUnciran 6. Pendeskripsian tersebut meliputi rumusan indikator, pengembangan materi pembelajaran, perancangan langkah-langkah pembelajaran, pemilihan sumber dan media pembelajaran, dan perencanaan penilaian.

\section{METODE PENELITIAN}

Rancangan penelitian ini tergolong jenis penelitian kualitatif. Menurut Moleong (2005: 4), penelitian kualitatif adalah prosedur penelitian yang menghasilkan data deskriptif berupa kata-kata tertulis atau lisan dari orang-orang dan perilaku yang dapat diamati. Penelitian ini dilakukan di SD Negeri Kunciran 6. Waktu pelaksanaan penelitian dilakukan secara bersama tetapi bertahap. 
Instrumen penelitian ini adalah buman instrument, yaitu peneliti berfungsi menetapkan fokus penelitian, memilih informan sebagai sumber data, melakukan pengumpulan data, menilai kualitas data, analisis data, menafsirkan data, membuat kesimpulan atas temuannya, dan akhirnya peneliti menjadi pelapor hasil penelitiannya. Data yang diperoleh berupa data verbal, yaitu berupa informasi yang diperoleh dari RPP Bahasa Inggris yang digunakan guru Bahasa Inggris di SD Negeri Kunciran 6. Sumber data adalah subyek dari mana data dapat diperoleh (Arikunto, 2006: 129). Sumber data utama dalam penelitian ini ialah RPP Bahasa Inggris di SD Negeri Kunciran 6

Langkah-langkah analisis yang digunakan dalam penelitian ini sebagai berikut. Proses analisis data dalam penelitian ini yang berupa studi dokumentasi adalah peneliti mengumpulkan RPP yang digunakan guru Bahasa Inggris di SD Negeri Kunciran 6. Setelah itu, RPP terkumpul dan data diklasifikasikan berdasarkan kelas, empat keterampilan berbahasa, dan kompetensi dasar. RPP dianalisis sesuai dengan komponen yang diamati dalam Rubrik Panduan Penyusunan RPP dengan menggunakan chek list. Dalam penelitian ini, rubrik tidak digunakan untuk menilai melainkan digunakan sebagai panduan proses analisis data (analisis verbal). Analisis pada Rubrik Panduan Penyusunan RPP diberi tanda $(\sqrt{ })$ jika aspek yang terdapat dalam RPP yang diteliti sesuai dengan kriteria dalam Rubrik Panduan Penyusunan RPP, tetapi jika tidak maka diberi tanda (X). Langkah selanjutnya adalah analisis verbal dari hasil chek list. Peneliti menjabarkan/mendeskripsikan hasil chek list secara verbal berdasarkan teori tentang komponen RPP dan pengembangannya. Teori tersebut digunakan untuk menunjang data tentang (1) pengidentifikasian indikator dalam pencapaian kompetensi, (2) pengembangan materi pembelajaran, (3) penentuan skenario pembelajaran, (4) penentuan media dan sumber belajar, dan (5) perencanaan penilaian.

Keabsahan data yang dilakukan dalam penelitian ini dilakukan dengan cara berikut. Pertama, peneliti membaca dan menelaah semua sumber data secara berulangulang sehingga menjadi wujud dari perpanjangan pengamatan. Kedua, peneliti membaca secara intensif dan mengamati secara teliti dan mendalam seluruh RPP yang telah dikumpulkan. Ketiga, peneliti menggunakan teknik trianggulasi. 
Trianggulasi adalah teknik pemeriksaan keabsahan data yang memanfaatkan sesuatu yang lain di luar data itu untuk keperluan pengecekan atau sebagai pembanding terhadap data itu (Moleong, 2005: 330).

\section{HASIL PENELITIAN DAN PEMBAHASAN}

Berdasarkan data yang diperoleh, diketahui bahwa RPP yang diamati berjumlah 24 RPP yang terdiri dari 6 RPP keterampilan mendengarkan, 6 RPP keterampilan berbicara, 6 RPP keterampilan membaca, dan 6 RPP keterampilan menulis. Hasil penelitian yaitu rumusan indikator RPP telah mencakup aspek kejelasan dan kelengkapan cakupan indikator. Rumusan indikator masih kurang rinci dan rumusan indikator sebagian RPP menyalin apa adanya dari kompetensi dasar, sehingga menimbulkan penafsiran ganda dan kurang menggambarkan tahapan dalam pencapaian kompetensi. Dari RPP empat keterampilan, RPP keterampilan berbicara paling sesuai dan mencakup aspek rumusan indikator, sedangkan RPP keterampilan mendengarkan paling tidak sesuai dengan aspek rumusan inikator. Kesesuaian dan ketidaksesuaian tersebut dapat dilihat pada contoh penjabaran indikator RPP BCR1 dan DGR5.

Pengembangan materi telah mengacu pada indikator pembelajaran dan dapat digunakan untuk mencapai kompetensi dasar. Sebagian RPP berupa pencantuman pokok-pokok materi saja tanpa dilampirkan penjelasan tentang materi pembelajaran. Dari RPP empat keterampilan, RPP keterampilan menulis paling sesuai dengan aspek pengembangan materi pembelajaran, sedangkan RPP keterampilan membaca paling tidak sesuai dengan aspek pengembangan materi pembelajaran. Kesesuaian dan ketidaksesuaian tersebut dapat dilihat pada contoh penjabaran pengembangan materi pada RPP TLS1 dan RPP BCA.

Perencanaan langkah-langkah pembelajaran telah mencakup kegiatan pendahuluan, kegiatan inti, dan kegiatan penutup. Kegiatan pendahuluan telah mencakup aspek menyampaian tujuan pembelajaran/menyampaikan apersepsi awal tentang materi yang akan dipelajari, tetapi belum mencakup aspek mengaitkan kehidupan nyata dan pengetahuan terdahulu dengan $\mathrm{KD}$, dan guru belum 
mendemonstrasikan sesuatu berkaitan dengan KD. Pada kegiatan inti, langkahlangkah pembelajaran telah mencakup aspek memberi kesempatan siswa aktif dan memungkinkan tumbuhnya kebiasaan positif. Akan tetapi, para guru belum menjabarkan tahapan-tahapan pencapaian indikator/KD secara tepat. Pada kegiatan penutup, guru masih banyak yang belum mengarahkan membuat penguatan, memeriksa hasil belajar, dan belum memberikan arahan tindak lanjut pembelajaran. Kesesuaian kegiatan pendahuluan, kegiatan inti, kegiatan penutup dapat dilihat pada penjabaran langkah-langkah kegiatan pembelajaran RPP DGR6 dan RPP DGR3.

Pemilihan sumber belajar dan media pembelajaran telah sesuai dengan aspek kesesuaian indikator, mudah diterapkan, dan memberikan kesempatan untuk berpartisipasi aktif. Guru hanya mencantumkan sumber belajar dan media pembelajaran, sedangkan ketersediaan wujud sumber belajar dan media pembelajaran tidak dilampirkan pada RPP. Pencantuman pemilihan sumber dan media pembelajaran kurang rinci karena tidak menuliskan secara jelas sumbernya. Dari RPP empat keterampilan, RPP keterampilan mendengarkan paling sesuai dengan aspek pemilihan sumber dan media pembelajaran, sedangkan RPP keterampilan membaca paling tidak sesuai dengan aspek pemilihan sumber dan media pembelajaran. Kesesuaian dan ketidaksesuaian tersebut dapat dilihat pada contoh penjabaran pemilihan sumber dan media pembelajaran pada RPP DGR1 dan RPP BCA1.

Perencanaan penilaian telah dilengkapi instrumen yang sesuai dengan indikator dan telah dicantumkan bentuk dan teknik penilaian. Perencanaan penilaian belum mencakup seluruh indikator, dan sebagian alat penilaian tidak disertai dengan kriteria penilaian. Dari RPP empat keterampilan, RPP keterampilan berbicara paling sesuai dengan aspek perencanaan penilaian, sedangkan RPP keterampilan membaca paling tidak sesuai dengan aspek perencanaan penilaian. Kesesuaian dan ketidaksesuaian tersebut dapat dilihat pada contoh penjabaran perencanaan penilaian pada RPP BCA3 dan RPP BCA6. 


\section{PEMBAHASAN}

Menurut Mulyasa (2007: 205), indikator adalah penjabaran dari kompetensi dasar yang menunjukkan tanda-tanda, perbuatan dan respon yang dilakukan atau ditampilkan oleh peserta didik. Indikator dirumuskan dalam kata kerja operasional yang dapat diukur dan dapat diobservasi, sehingga dapat digunakan sebagai dasar dalam menyusun alat penilaian.

Rumusan indikator RPP telah mencakup aspek kejelasan dan kelengkapan cakupan indikator. Dari RPP empat keterampilan, RPP keterampilan berbicara paling sesuai dan mencakup aspek rumusan indikator, sedangkan RPP keterampilan mendengarkan paling tidak sesuai dengan aspek rumusan indikator. Kesesuaian dan ketidaksesuaian tersebut dapat dilihat pada contoh penjabaran indikator RPP BCR1 dan RPP DGR5. Berdasarkan penjabaran RPP BCR1, dapat diketahui bahwa rumusan indikator telah sesuai dengan aspek rumusan indikator. Dikatakan demikian karena penjabaran indikator sesuai kompetensi dasar yaitu 'bercerita dengan urutan yang baik, suara, intonasi, gestur, dan mimik yang tepat'. Rumusan indikator juga menunjang pencapaian kompetensi dan tidak menimbulkan penafsiran ganda. Ini tampak dari indikator yang telah mengandung pokok-pokok cerita, bercerita dengan urutan yang baik, dengan suara, intonasi, gesture, dan mimik yang tepat. Rumusan indikator juga mengandung perilaku yang merupakan hasil belajar yaitu siswa ditugasi untuk bercerita dengan baik dengan suara, intonasi, gesture, dan mimik yang tepat.

Berdasarkan penjabaran RPP DGR5, dapat diketahui bahwa rumusan indikator tidak sesuai dengan kompetensi dasar. Indikator 'menyusun pertanyaan untuk berdialog' tidak sesuai dengan kompetensi dasar 'menyimpulkan isi dialog interaktif beberapa narasumber pada tayangan televisi/siaran radio'. Pada indikator tersebut, siswa disuruh 'membuat/ menyusun daftar pertanyaan yang selanjutnya akan digunakan untuk berdialog'. Indikator yang mengarahkan 'siswa membuat penyimpulan terbadap dialog' juga tidak dicantumkan sehingga kompetensi dasar RPP tersebut tidak akan tercapai. Rumusan indikator RPP DGR5 tersebut tidak sesuai dengan pendapat Majid (2011: 53) yang menyatakan bahwa indikator merupakan kompetensi dasar secara spesifik yang dapat dijadikan ukuran untuk mengetahui ketercapaian hasil pembelajaran. Indikator 
dirumuskan dengan kata kerja operasional yang bisa diukur dan dibuat instrumen penilaiannya.

Penulis menemukan satu RPP yaitu TLS4 yang indikatornya dicantumkan sama persis dengan $\mathrm{KD}$, yaitu 'memerankan naskah drama yang ditulis siswa'. Guru hanya menyalin apa adanya dari KD sehingga indikator yang dijabarkan tersebut kurang menggambarkan tahapan peserta didik dalam mencapai kompetensi pembelajaran. Hal tersebut dijelaskan oleh Mulyasa (2007: 205) bahwa indikator adalah penjabaran dari kompetensi dasar yang menunjukkan tanda-tanda, perbuatan dan respon yang dilakukan oleh peserta didik. Indikator dirumuskan dalam kata kerja operasional yang dapat diukur dan dapat diobservasi, sehingga dapat digunakan sebagai dasar dalam menyusun alat penilaian. Apabila indikator dirumuskan sama persis dengan KD maka tidak ada penjabaran KD menjadi indikator yang lebih spesifik dan operasional sehingga peran indikator sebagai penanda keberhasilan pembelajaran tidak dapat terwujud.

\section{Pengembangan Materi Pembelajaran RPP Bahasa Inggris di SD Negeri Kunciran 6}

Mulyasa (2007: 225) menjelaskan bahwa materi pembelajaran adalah bahan pembelajaran berkenaan dengan sesuatu yang harus dipelajari oleh peserta didik untuk memperoleh kompetensi. Materi pembelajaran merupakan isi kurikulum yang diberikan kepada peserta didik sesuai dengan indikator yang telah disusun sebelumnya. Materi pembelajaran menggambarkan semua kompenesi yang akan dicapai dalam indikator. Menurut Susilo (2007: 120), materi pembelajaran adalah pokok-pokok materi pelajaran yang harus dipelajari siswa sebagai sarana pencapaian kemampuan dasar yang akan dinilai dengan menggunakan instrumen penilaian yang disusun berdasarkan indikator pencapaian belajar. Materi yang diajarkan perlu diidentifikasi apakah termasuk fakta, konsep, prinsip, prosedur, atau gabungan lebih dari satu jenis materi. Dengan mengidentifikasi jenis-jenis materi yang akan diajarkan, maka guru akan mendapatkan kemudahan dalam cara mengajarnya. 
Pengembangan materi telah mengacu pada indikator pembelajaran dan dapat digunakan untuk mencapai kompetensi dasar. Dari RPP empat keterampilan, RPP keterampilan menulis paling sesuai dengan aspek pengembangan materi pembelajaran, sedangkan RPP keterampilan membaca paling tidak sesuai dengan aspek pengembangan materi pembelajaran. Akan tetapi, hampir semua RPP berupa pencantuman pokok-pokok materi saja tanpa dilampirkan penjelasan tentang materi pembelajaran. Kesesuaian dan ketidaksesuaian tersebut dapat dilihat pada contoh penjabaran pengembangan materi pada RPP TLS1 dan RPP BCA1.

Berdasarkan penjabaran RPP TLS1 dapat diketahui bahwa pengembangan materi telah mengacu pada indikator 'menentukan syarat-syarat pantun, menulis pantun, dan menyunting pantun sesuai dengan syarat-syarat pantun', sehingga dapat dipakai untuk mencapai indikator dalam pencapaian kompetensi 'menulis pantun yang sesuai dengan syarat-syarat pantun', sehingga materi tersebut dapat dipakai untuk pencapaian kompetensi dasar. Penjabaran materi tersebut sesuai pendapat Sukmadinata dan Ibrahim (2003: 100) bahwa materi pelajaran merupakan salah satu unsur atau komponen yang penting untuk mencapai tujuan pengajaran. Apabila materi tidak sesuai dengan KD maka materi tersebut tidak dapat menunjang pencapaian kompetensi dasar.

Pengembangan materi pada RPP BCA1 tidak sejalan dengan pendapat Majid (2011: 44) yang menyatakan bahwa materi pokok adalah pokok-pokok materi pembelajaran yang harus dipelajari siswa sebagai sarana pencapaian kompetensi dan yang akan dinilai dengan menggunakan instrumen yang disusun berdasar indikator pencapaian belajar. Pengembangan materi RPP BCA1 tersebut tidak mencantumkan penjelasan materi pembelajaran, sehingga keakuratan dan kebenaran dari materi tidak dapat diketahui. Pada RPP tersebut hanya disebutkan materi pembelajaran terdiri dari pembacaan berbagai teks perangkat upacara, Teks Pancasila, teks Pembukaan UUD 1945, teks janji siswa, dan doa. Meskipun telah mengacu pada indikator, tetapi materi tersebut belum ada penjelasan materi tentang 'pembacaan yang sesuai dengan pelafalan yang baik, intonasi yang tepat' sehingga kompetensi dasar tidak dapat tercapai. 
Perencanaan Langkah-langkah Pembelajaran RPP Bahasa Inggris di SD Negeri Kunciran 6

Pengalaman dan kegiatan pembelajaran dapat diartikan sebagai kegiatan belajar yang perlu dilakukan oleh siswa dalam berinteraksi dengan objek dan sumber belajar untuk mencapai penguasaan kompetensi dasar. Berbagai alternatif pengalaman belajar/kegiatan belajar dapat dipilih sesuai dengan jenis kompetensi serta materi yang dipelajari (Priyatni, 2009: 21). Selain itu, Efendi (2009: 122) menjelaskan bahwa kegiatan pembelajaran memuat rangkaian kegiatan yang harus dilakukan oleh peserta didik secara berurutan untuk mencapai kompetensi dasar. Penentuan urutan kegiatan pembelajaran harus sesuai dengan hierarki konsep materi pembelajaran.

Berdasarkan hasil penelitian, semua RPP telah mencantumkan langkah-langkah pembelajaran yang terdiri dari kegiatan pendahuluan, kegiatan pencapaian kompetensi/inti, dan kegiatan penutup. Hal tersebut sesuai dengan pendapat Mulyasa (2008: 185) bahwa pelaksanaan kegiatan pembelajaran mencakup tiga kegiatan yaitu pembukaan, pembentukan kompetensi/inti, dan penutup.

Kegiatan pendahuluan telah mencakup aspek menyampaian tujuan pembelajaran/menyampaikan apersepsi awal tentang materi yang akan dipelajari, tetapi belum mencakup aspek mengaitkan kehidupan nyata dan pengetahuan terdahulu dengan $\mathrm{KD}$, dan sedikit sekali guru yang mendemonstrasikan sesuatu berkaitan dengan KD. Pada kegiatan inti, langkah-langkah pembelajaran telah telah mencakup aspek memberi kesempatan siswa aktif dan memungkinkan tumbuhnya kebiasaan positif, tetapi para guru belum menjabarkan tahapan-tahapan pencapaian indikator/KD secara tepat. Pada kegiatan penutup, guru masih banyak yang belum mengarahkan membuat penguatan, memeriksa hasil belajar, dan belum memberikan arahan tindak lanjut pembelajaran. Kegiatan penutup sebagian besar diisii dengan bertepuk tangan dan meneriakkan yel-yel sebagai tanda keberhasilan pembelajaran, dan melakukan refleksi. Kesesuaian kegiatan pendahuluan, kegiatan inti, kegiatan penutup dapat dilihat pada penjabaran langkah-langkah kegiatan pembelajaran RPP DGR6 dan RPP DGR3. 
Berdasarkan penjabaran RPP DGR6, dapat diketahui bahwa pada kegiatan pendahuluan, telah mencakup aspek mengaitkan pengetahuan/pengalaman terdahulu dengan KD yang akan dicapai yaitu terlihat dari guru menggali pengetabuan awal tentang dialog, sedangkan aspek menyampaikan tujuan pembelajaran (adanya apersepsi awal tentang materi yang akan dipelajari) dapat dilihat dari guru menjelaskan kompetensi yang akan dicapai dan kegunaannya dalam kehidupan sehari-bari. Penjabaran kegiatan pendahuluan tersebut telah sesuai dengan pendapat Mulyasa (2008: 181) bahwa kegiatan pembukaan dapat dilakukan dengan upaya menyampaikan tujuan yang akan dicapai dan garis besar materi yang akan dipelajari, mengajukan pertanyaan baik untuk mengetahui pemahaman peserta didik terhadap pembelajaran yang telah lalu atau untuk menjajagi kemampuan awal berkaitan dengan bahan yang akan dipelajari.

Perencanaan langkah-langkah kegiatan pada kegiatan inti sesuai pendapat Efendi (2009: 122) yang menjelaskan bahwa kegiatan pembelajaran memuat rangkaian kegiatan yang harus dilakukan oleh peserta didik secara berurutan untuk mencapai kompetensi dasar. Penentuan urutan kegiatan pembelajaran harus sesuai dengan hierarki konsep materi pembelajaran. Penjabaran kegiatan inti tersebut telah mencakup aspek tahapan-tahapan pencapaian kompetensi. Hal tersebut ditunjukkan dengan kegiatan inti yang dimulai dari mendengarkan rekaman, mendata pendapat tiap-tiap narasumber, bertanya jawab mengenai pendapat narasumber, dan mengomentari pendapat tiap-tiap narasumber yang semuanya mengacu pada kompetensi dasar sehingga pencapaian kompetensi dasar dapat tercapai. Kegiatan inti juga mencakup aspek berfokus pada siswa dan memungkinan tumbuh kebiasaan positif siswa. Hal tersebut dapat ditunjukkan pada kegiatan yang mengarahkan siswa untuk melakukan diskusi dan tanya jawab dalam kelompok secara cermat, percaya diri dan santun.

Aspek kesesuaian pada kegiatan penutup pembelajaran dapat dilihat dari penjabaran RPP DGR3 yang telah sesuai dengan aspek penyusunan langkah-langkah kegiatan penutup. Penjabaran kegiatan penutup tersebut telah sesuai dengan pendapat Mulyasa (2008: 186) yang menjelaskan bahwa kegiatan penutup mencakup kegiatan menarik kesimpulan/meninjau kembali mengenai materi yang telah dipelajari, mengadakan evaluasi/penilaian, dan memberikan tindak lanjut terhadap materi yang telah dipelajari. Kesesuaian tersebut dapat dilihat pada kegiatan penutup RPP DGR3. 


\section{Pemilihan Media dan Sumber Belajar RPP Bahasa Inggris di SD Negeri Kunciran 6}

Sumber belajar adalah rujukan objek dan/atau bahan yang digunakan untuk kegiatan pembelajaran, yang berupa media cetak dan elektronik, nara sumber, serta lingkungan fisik, alam, sosial, dan budaya. Penentuan sumber belajar didasarkan pada standar kompetensi dan kompetensi dasar serta materi pokok/pembelajaran, kegiatan pembelajaran, dan indikator pencapaian kompetensi (Supinah, 2008: 11). Menurut Majid (2011: 59), sumber belajar ditetapkan sebagai informasi yang disajikan dan disimpan dalam berbagai bentuk media, yang dapat membantu siswa dalam belajar sebaga perwujudan dari kurikulum.

Pemilihan sumber belajar dan media pembelajaran telah sesuai dengan aspek kesesuaian indikator, mudah diterapkan, dan memberikan kesempatan untuk berpartisipasi aktif. Akan tetapi, guru hanya mencantumkan sumber belajar dan media pembelajaran, sedangkan ketersediaan wujud sumber belajar dan media pembelajaran belum dilampirkan pada RPP. Pencantuman juga tidak sesuai kriteria seperti yang dijelaskan Majid (2011: 61) bahwa salah satu cara menuliskan sumber bahan adalah dengan menuliskan nama pengarang, tahun terbitan, judul buku, tempat penerbitan, dan nama penerbit. Sebagian besar RPP hanya dicantumkan jenis sumber dan media saja tanpa menuliskan sumbernya dengan benar.

Dari RPP empat keterampilan, RPP keterampilan mendengarkan paling sesuai dengan aspek pemilihan sumber dan media pembelajaran, sedangkan RPP keterampilan membaca paling tidak sesuai dengan aspek pemilihan sumber dan media pembelajaran. Kesesuaian dan ketidaksesuaian tersebut dapat dilihat pada contoh penjabaran pemilihan sumber dan media pembelajaran RPP DGR1 dan RPP BCA1. Pada RPP DGR1 siswa disurub mendengarkan berita yang dibacakan dari sumber belajar, sehingga siswa dapat menyimpulkan isi berita. Dengan kata lain, dengan adanya sumber belajar yang sesuai indikator tersebut kompetensi dapat tercapai. Penjabaran RPP BCA1 tidak dilampirkan wujud sumber dan media pembelajaran. 


\section{Perencanaan Penilaian RPP Bahasa Inggris di SD Negeri Kunciran 6}

Untuk kegiatan penilaian membutuhkan alat penilaian dalam mencapai indikator dan guru perlu menentukan alat penilaian sesuai dengan kompetensi yang akan dinilai. Muslich (2008: 46) menambahkan bahwa jika instrumen penilaian berbentuk tugas, harus dirumuskan tugas tersebut secara jelas dan bagaimana rambu-rambu penilaiannya. Jika instrumen penilaian berbentuk soal, soal-soal harus dicantumkan dan ditentukan rambu-rambu penilaiannya dan/atau kunci jawabannya. Jika penilaian berbentuk proses, harus disertakan rubrik dan indikator masing-masing.

Perencanaan penilaian telah dilengkapi instrumen yang sesuai dengan indikator dan telah mencantumkan bentuk dan teknik penilaian. Akan tetapi, perencanaan penilaian belum mencakup seluruh indikator, dan masih banyak alat penilaian yang tidak disertai dengan kriteria penilaian. Dari RPP empat keterampilan, RPP keterampilan berbicara paling sesuai dengan aspek perencanaan penilaian, sedangkan RPP keterampilan membaca paling tidak sesuai dengan aspek perencanaan penilaian. Kesesuaian dan ketidaksesuaian tersebut dapat dilihat pada contoh penjabaran perencanaan penilaian pada RPP BCA3 dan RPP BCA6.

Berdasarkan penjabaran penilaian RPP BCA6 dapat diketahui bahwa perencanaan penilaian RPP tersebut telah mencakup kesesuaian alat penilaian. Hal itu dapat dilihat dari pencantuman teknik dan bentuk penilaian, dan melampirkan instrumen beserta kriteria penilaian, dan penilaian mencakup seluruh indikator. Penjabaran tersebut telah sesuai dengan pendapat Majid (2011: 187) yang menyatakan bahwa penilaian harus menggunakan berbagai ukuran, metode, dan kriteria yang sesuai dengan karakteristik dan esensi pengalaman belajar. Penilaian harus mencakup semua aspek dari tujuan pembelajaran. Temukanlab secara cepat dan tepat 3 kata berindeks yang disediakan gurumu, dan temukanlab kata berikut dalam buku telah sesuai dengan indikator/kompetensi dasar 'menemukan informasi yang diperlukan secara cepat dan tepat indeks buku melalui kegiatan membaca memindai.

Ketidaksesuaian terlihat pada penjabaran RPP BCA3 yang perencanaan penilaian tidak mencakup aspek kesesuaian penilaian. Pada RPP tersebut hanya dicantumkan dua soal/pertanyaan dan satu kriteria penilaian. Perencanaan penilaian tersebut tidak sesuai dengan penjelasan Priyatni (2009: 8) yang menyatakan bahwa penilaian 
dilakukan dengan menilai semua indikator yang tercantum dalam kompetensi dasar bukan sampling. Semua indikator yang tercantum dalam setiap kompetensi dasar diukur dengan alat ukur yang jelas. Akan tetapi, pada RPP tersebut perencanaan penilaian tidak mencakup seluruh indikator, serta membingungkan karena tidak ada kejelasan indikator mana yang dinilai dengan instrumen/soal tersebut, serta tidak mencantumkan teknik dan bentuk penilaian.

\section{KESIMPULAN}

Rumusan indikator RPP yang digunakan guru Bahasa Inggris di SD Negeri Kunciran 6 telah mencakup aspek kejelasan dan kelengkapan cakupan indikator. Rumusan indikator masih kurang rinci dan sebagian indikator RPP menyalin apa adanya dari kompetensi dasar sehingga menimbulkan penafsiran ganda dan kurang menggambarkan tahapan dalam pencapaian kompetensi.

Perencanaan pengembangan materi RPP yang digunakan guru Bahasa Inggris di SD Negeri Kunciran 6 telah mengacu pada indikator pembelajaran dan dapat digunakan untuk mencapai kompetensi dasar. Hampir semua RPP berupa pencantuman pokokpokok materi saja tanpa dilampirkan penjelasan tentang materi pembelajaran, sehingga aspek kebenaran/keakuratan materi secara teori tidak dapat diketahui.

Perencanaan kegiatan pembelajaran RPP yang digunakan guru Bahasa Inggris di SD Negeri Kunciran 6 mencakup kegiatan pendahuluan, kegiatan inti, dan kegiatan penutup. Kegiatan pendahuluan mencakup aspek menyampaikan tujuan pembelajaran, tetapi belum mencakup aspek mengaitkan kehidupan nyata dan pengetahuan terdahulu dengan KD, dan sedikit sekali guru yang mendemonstrasikan sesuatu berkaitan dengan KD. Pada kegiatan inti, langkah-langkah pembelajaran telah mencakup aspek memberi kesempatan siswa aktif dan memungkinkan tumbuhnya kebiasaan positif, tetapi para guru belum menjabarkan tahapan-tahapan pencapaian indikator/KD secara tepat. Pada kegiatan penutup, guru belum mengarahkan membuat penguatan, memeriksa hasil belajar, dan belum memberikan arahan tindak lanjut pembelajaran. Sebagian besar guru mengisi kegiatan penutup dengan bertepuk tangan, meneriakkan yel-yel dan kegiatan refleksi. 
Perencanaan pemilihan sumber belajar dan media pembelajaran Bahasa Inggris di SD Negeri Kunciran 6 sesuai dengan aspek kesesuaian indikator, mudah diterapkan, dan memberikan kesempatan untuk berpartisipasi aktif. Guru hanya mencantumkan sumber belajar dan media pembelajaran, sedangkan ketersediaan wujud sumber belajar dan media pembelajaran belum dilampirkan pada RPP.

Perencanaan penilaian RPP Bahasa Inggris di SD Negeri Kunciran 6 telah dilengkapi instrumen yang sesuai dengan indikator dan telah mencantumkan bentuk dan teknik penilaian. Akan tetapi, perencanaan penilaian belum mencakup seluruh indikator, dan masih banyak alat penilaian yang tidak disertai dengan kriteria penilaian.

\section{DAFTAR PUSTAKA}

Arikunto, S. 2006. Prosedur Penelitian: Suatu Pendekatan Praktik. Jakarta: Rineka Cipta.

Efendi, M. 2009. Kurikulum dan Pembelajaran: Pengantar ke Arab Pemahaman KBK, KTSP, dan SBI. Malang: Universitas Negeri Malang.

Majid, A. 2011. Perencanaan Pembelajaran: Mengembangkan Standar Kompetensi Guru. Bandung: Rosdakarya.

Moleong, L. 2005. Metode Penelitian Kualitatif. Bandung: Rosdakarya.

Mulyana, A. 2012. Inovasi Pendidikan Diawali dari Inovasi Pengembangan Rencana Pelaksanaan Pembelajaran (RPP). (online) (http://ainamulyana.blogspot.com/2012/02/inovasi-pendidikan-dapat-diawalidari.html), diakses diakses 24 Mei 2012.

Mulyasa, E. 2007. Kurikulum Tingkat Satuan Pendidikan: Suatu Panduan Praktis. Bandung: Remaja Rosdakarya.

Mulyasa, E. 2008. Implementasi Kurikulum Tingkat Satuan Pendidikan: Kemandirian Guru dan Kepala Sekolah. Jakarta: Bumi Aksara.

Muslich, M. 2008. Kurikulum Tingkat Satuan Pendidikan: Dasar Pemahaman dan Pengembangan. Jakarta: Bumi Aksara.

Priyatni, E.T. 2009. Buku Petunjuk Teknis Praktik Pengalaman Lapangan Bidang Studi Pendidikan Bahasa dan Sastra Indonesia. Malang: Universitas Negeri Malang.

Sukmadinata, N.S dan Ibrahim R. 2003. Perencanaan Pengajaran. Jakarta Rineka Cipta.

Supinah. 2008. Penyusunan Silabus dan Rencana Pelaksanaan (RPP) Matematika SD dalam Rangka Pengembangan KTSP (H.W. Sasongko, Ed). Yogjakarta: Departemen Pendidikan Nasional. Pusat Pengembangan dan Pemberdayaan Pendidik dan Tenaga Kependidikan Matematika. (online),(http://p4tkmatematika.org/fasilitasi/10-SilabusRPP-Supinah.pdf), diakses 24 Mei 2012.

Susilo, M.J. 2007. Kurikulum Tingkat Satuan Pendidikan: Managemen Pelaksanaan dan Kesiapan Sekolah menyongsongnya. Yogyakarta. Pustaka Pelajar. 